\title{
LIGA プロセスを用いた射出成形金型の開発
}

黑 川 正 也*

\section{1.はじめに}

MEMS（Micro Electro Mechanical Systems）技術を用 いてマイクロメータあるいはナノメータレベルの微細な構 造をシリコン基板上に加工する研究開発(1) 3) が，バイオ, 医療，通信，ならびに光分野への応用展開を目指して, 1990 年代頃から急速に行われるようになった。これらの研究を 通してマイクロメータからナノメータレベルの微細な構造 をシリコン基板上に形成できるようになり，製作したシリ コン加工品による性能評価, あるいは製作したシリコン加 工品を鋳型としてシリコーン樹脂 (Polydimethyl siloxane : PDMS）製のレプリカ品による性能評価が行えるよ うになってきた. しかし，これらの評価では，評価に使え る加工品が 1 枚あるいは数枚程度であり, 将来の三次元構 造体の量産化には繋がらない.このような状況下, 基礎研 究から得られた結果を基に, 三次元構造体を大量生産する プロセスの開発機運が高まりつつあり, 製造コストの低減 およびマイクロメータからナノメータレベルの再現精度な どの量産対応要求を解決できる製造プロセスの開発が進め られている。

このような開発機運の中, 三次元構造体の量産プロセス の 1 手法として，1982 年にドイツのカールスルーエ研究 センターに在籍していた Ehrfeld らが提案した LIGA プロ セス ${ }^{4)}$ が着目されている. LIGA プロセスは，シンクロト ロン放射光 (Synchrotron Radiation: SR) のX 線用いた リソグラフィ (Lithographie), 電気メッキ (Galvanoformung), 成形 (Abformung) の頭文字から称したプロセ スで, 射出成形で三次元構造体を大量生産することを特徵 としたプロセスである.

射出成形プロセスという生産プロセスでは, 所望する成 形品の微細パターン形状を反転させた形状の金型を作るこ とができれば, 成形条件の最適化検討により三次元微細構 造体を, マイクロメータあるいはナノメータレベルの形状 再現性で大量生産できることから，上述したようなバイオ， 医療, 通信, ならびに光分野への製品を高精度の形状再現 性で大量生産が可能となる.しかし, 数十 $\mu \mathrm{m}$ から数百 $\mu \mathrm{m}$ といった三次元構造を有する製品を射出成形で成形するた

\footnotetext{
* Kurokawa, Masaya

スターライト工業(侏) 精密製品事業本部 MD Project 滋賀県栗東市上砥山 2222（５520-3004）

2007.3.5 受理
}

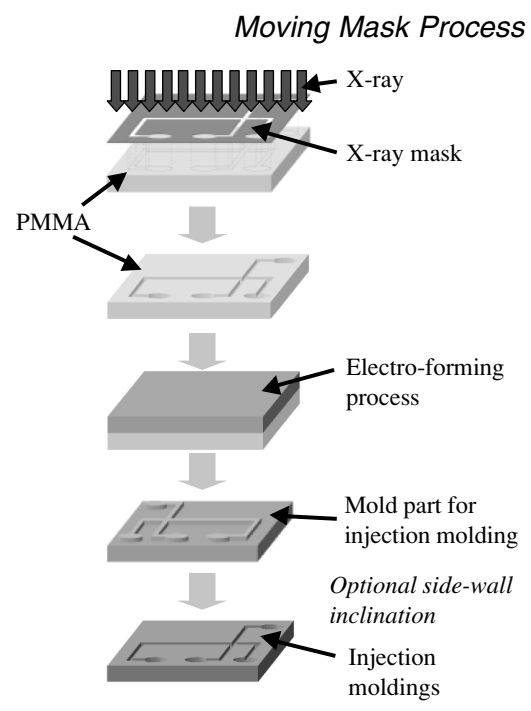

図 1 LIGA プロセスの説明

めには，通常の金型製作で用いられている機械加工で金型 を製作することは非常に難しいため，LIGA プロセスが着 目されている.

そこで，本報ではバイオ，医療，通信，ならびに光など の各分野に用いられるディスポーサブルな化学マイクロデ バイス（以下，マイクロデバイスと称す）を，射出成形で 生産するための LIGA プロセスならびに金型製作に関して 解説する. LIGA プロセスの各工程を図 1 に示す.

\section{2 ㄴIGA プロセス}

DNA チップ，プロテインチップ，ならびに環境ガス測 定チップなどに代表される，数十 $\mu \mathrm{m}$ から数百 $\mu \mathrm{m}$ 程度 の微細な三次元構造体を有するディスポーサブルなマイク ロデバイスを射出成形で製作後，そのデバイスの性能を評 価する研究が進んでいる(5) . 射出成形でマイクロデバイ スを製作する手法は，デバイスの微細な三次元形状を反転 させた金型入子を製作できれば，マイクロメータからナノ メータレベルの形状再現性で大量生産できるという特徽が ある.そこで，（1）金型鋼材へ直接加工する金型製作方法, (2) MEMS 技術でシリコン基板上に微細形状を加工した後, この加工基板をマスター型として電鋳金型を製作する方法, (3)リソグラフィを用いてレジスト基板上に微細形状を露 光した後，この基板をマスター型として電鋳金型を製作す 


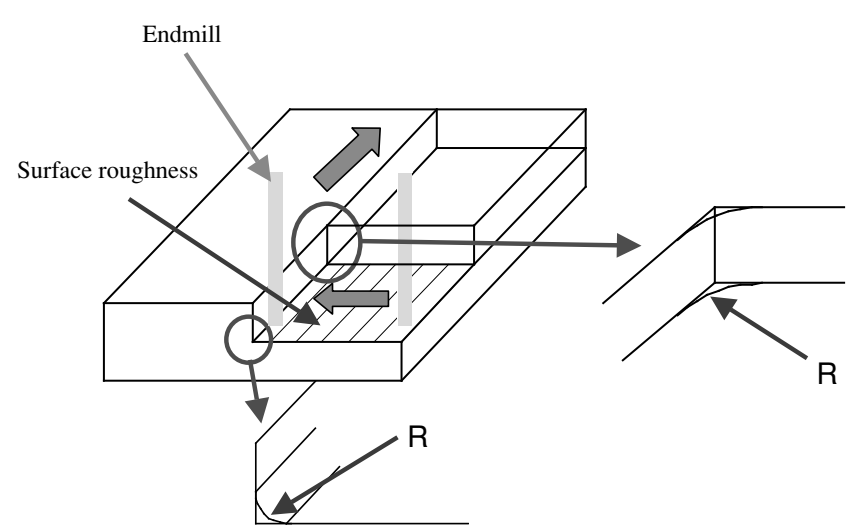

図 2 機械加工による金型製作

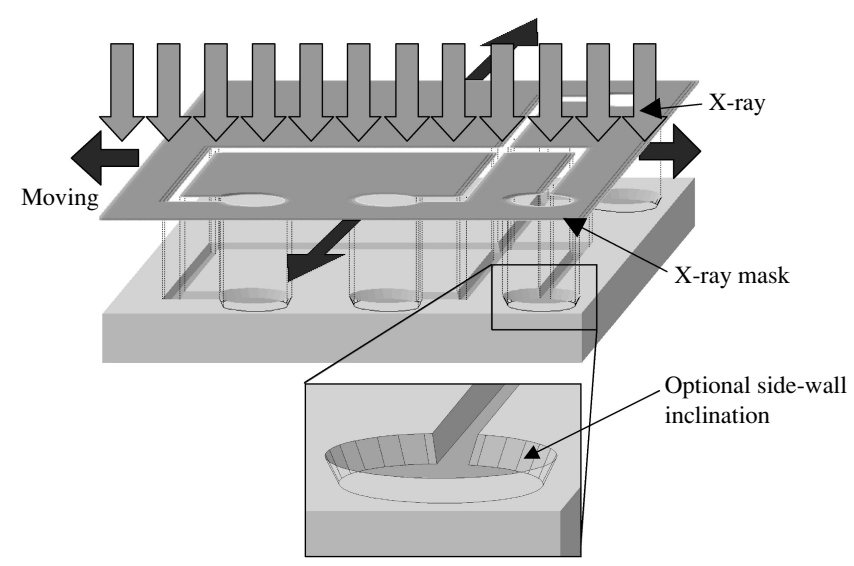

図 $3 \mathrm{SR}$ 露光工程における $\mathrm{X}$ 線移動マスク法

る方法など，射出成形金型の製作方法が検討されている. (1)の金型鋼材への直接加工に関しては, 超極細の切削バ イトによる切削加工，ならびに超極細ワイヤーによる放電 加工などで行われるが, 加工面の表面粗度, および加工面 のコーナーアールの存在（図 2）などにより，数十 $\mu \mathrm{m}$ か ら数百 $\mu \mathrm{m}$ 程度の微細形状の加工には用いられない場合 が多い。また，単結晶ダイヤモンドを用いた先進加工機に よる機械加工が検討されているが，マイクロあるいはナノ レベルの三次元自由曲面の加工が困難なことや加工エリア が制限されること等の問題がある。(2)の MEMS 技術を 用いたシリコン基板への微細加工に関しては，加工深さの バラツキおよび加工部のアスペクト比が 1 を超えると, 加 工断面の側壁が逆テーパ（アンダーカット）になる危険性 が高くなるという問題から，金型が製作できたとしても射 出成形工程で成形品が金型から取り出しにくい，あるいは 取り出せなくなる等の問題が懸念される。一方，(3)のリ ソグラフィを用いたレジスト基板への微細加工では, SR から出るサブナノメートルの波長を用いるため, 紫外線露 光と比べて光線の直線性が高く, 数百 $\mu \mathrm{m}$ の深さの露光 が一度にできる，さらに，図 3 に示すように露光時に X 線マスクとレジスト基板 (PMMA：Polymethylmethacrylate）とを相対的に移動させる (移動マスク法) ${ }^{8}$ こと で, PMMA 基板上に照射される X 線エネルギー（Dose） を制御し, 露光断面の側壁に任意の傾斜を付けることが可 能となる.この露光断面の側壁に順テーパの任意の傾斜角

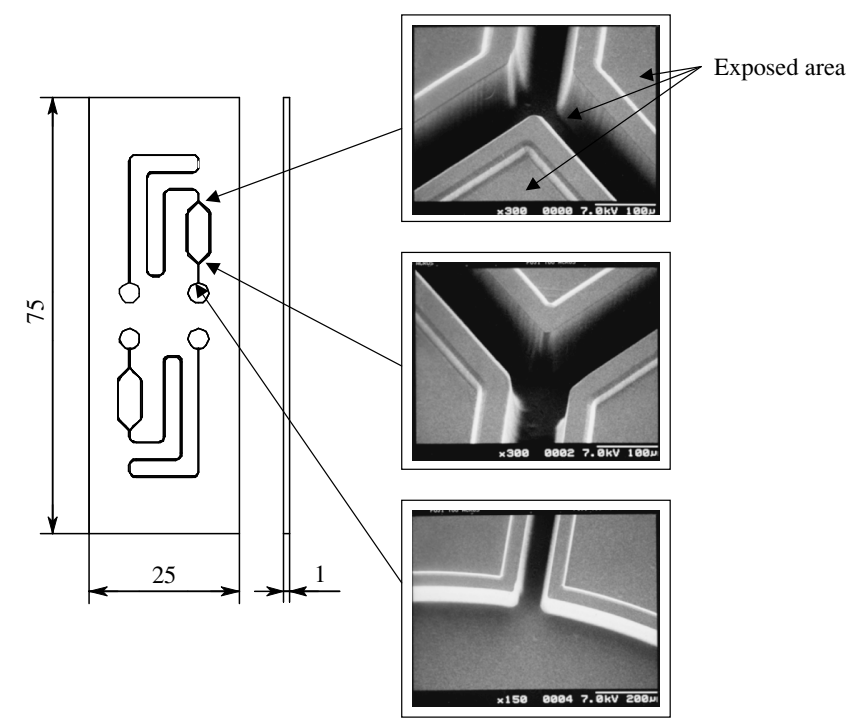

図 $4 \quad \mathrm{X}$ 線マスクによる PMMA 基板の露光状態

表 1 現像液

\begin{tabular}{l|c}
\hline \multicolumn{1}{c|}{ Solvent } & Concentration, wt $\%$ \\
\hline $2-(2-n-$ butoxy ethoxy $)$ ethanol & 60 \\
\hline Morpholine & 20 \\
\hline $2-$ amino ethanol & 5 \\
\hline $\mathrm{H}_{2} \mathrm{O}$ & 15 \\
\hline
\end{tabular}

を設定できることは，SRを用いた LIGA プロセスの大き な特徴である. 即ち, 射出成形時に微細パターン形状の転 写性を高めれば高めるほど，成形品が金型から離型しにく くなるという現象を，可能な限り微細形状の断面側壁に傾 斜を付けることでスムースな離型が可能となり, 離型工程 で成形品の形状を損ないにくくなる，さらに，スムースな 離型により金型の寿命が延びる可能性もある.

LIGA プロセスでは，X線マスクの製作が，マイクロデ バイスの製造コスト，品質などに大きく寄与して扮り，極 めて重要な要素である。一般的に，X線マスクはX 線透 過能力が高い材料である炭化ケイ素, 窒化ケイ素, カーボ ン，シリコン，あるいは高分子フィルムなどの薄膜基板上 に, X 線透過能力が低い材料である金, タンタル, あるい はタングステンで微細パターンが形成される．スターライ 卜工業侏では，マイクロデバイスの製造コストを下げる目 的で，このX線マスクの開発を進めている. 多数の試作 X 線マスクを製作検討した結果，図 4 に示すレベルのス ムースな露光表面粗度（Raが $0.1 \mu \mathrm{m} \sim 0.05 \mu \mathrm{m} ）$ に仕上 げられるX線マスクを製作できるようになっだ).

X 線マスクを図 1 に示すようにポジ型レジストである PMMA 基板の上に置き（露光時にX 線マスクと PMMA 基板とを相対的に移動させるため, X 線マスクと PMMA 基板との間に移動クリアランスを設けてある)，所定量の $\mathrm{X}$ 線エネルギーを PMMA 基板に照射させた後, 表 1 に示 す現像液に露光基板を浸析させることで，PMMA 基板上 に微細三次元構造体を形成させることができる。この PMMA 基板の微細パターン面に無電解メッキ，あるいは スパッタリングなどで導電化層を形成させた後, ニッケル 
(Ni) 電鋳工程に入る. $\mathrm{Ni}$ 電鋳工程では, 浴温度, 電流密 度, $\mathrm{pH}$ などを詳細に制御して内部応力の少ない $\mathrm{Ni}$ 電鋳 金型を製作する ${ }^{10)}$. 電鋳工程では電鋳の硬度を高める目的 で，純 $\mathrm{Ni}$ 以外に $\mathrm{Ni}-\mathrm{Fe}, \mathrm{Ni}-\mathrm{Co}$ などの $\mathrm{Ni}$ 系合金製の電鋳 工程が検討される場合があるが，合金系の電鋳は内部応力 の制御が純 $\mathrm{Ni}$ の場合より難しい. $\mathrm{Ni}$ 電鋳金型が完成後, この金型を射出成形用のモールドベースに組み込んで，成 形材料, 微細パターン形状, 成形品肉厚などから最適な射 出成形条件を設定する，射出成形では，射出成形金型が製 作でき,さらに最適成形条件を設定できれば, マイクロメー タからナノメータレベルの高い形状再現性で, マイクロデ バイスを 1 枚/分から数枚/分のスループットで大量生産す ることが可能となる. なお，スターライト工業(制では図 5 に示す立命館大学の SR 装置（Aurora）を用いて SR 露光 を行っている.

同装置で微細パターンを PMMA 基板に露光後, $\mathrm{Ni}$ 電

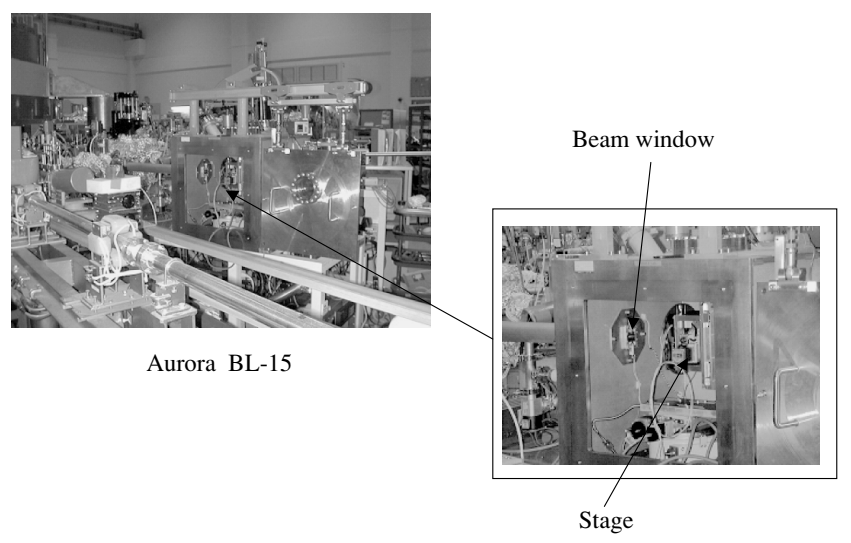

図 5 立命館大学 SR 施設（Aurora）
鋳金型を製作して，射出成形で PMMA を用いて 32 流路 電気泳動デバイスを成形した一例を図 6 に示す。同図より， $30 \mu \mathrm{m} \times 50 \mu \mathrm{m}$ の流路が交差している箇所が直角になって いる様子が観察される。このように流路交差部を直角に仕 上げる成形条件で，32 流路電気泳動デバイスを金型から スムースに離型させるには，流路の断面側壁に設けた傾斜 が重要となる。

\section{SR 露光における X 線回折の影響}

射出成形でマイクロデバイスを成形する場合, マイクロ デバイス上に形成される微細形状が複雑になればなるほど, さらに転写性の高い製品を成形しようとすればするほど, 微細形状の断面側壁に抜き勾配に相当する傾斜を設けるこ とが必要であることを前項で述べた。 その断面の側壁傾斜 角は, 微細形状に依存するが, おおよそ 10 度から 20 度程 度が必要と思われる.この断面に任意の傾斜角を設けるに は図 3 に示したようにSR 露光プロセスで, PMMA 基板 に照射される X 線エネルギーを制御するため, X 線マス クと PMMA 基板とを相対移動させるための X 線マスク と PMMA 基板との間に移動クリアランスが必要となる. しかし，この移動クリアランスを大きく設定すると，サ ブナノメートルの波長の X 線を用いても SR 露光工程で $\mathrm{X}$ 線回折現象が生じることが確認された ${ }^{11)}$. 以下に X 線回折 の影響に関して検討した一例を簡潔にまとめた。

図 7 に X 線マスクに形成した微細パターンレイアウト を示す．微細パターンは，5，10，15，20，25，30，35，40， 45，50，60，70，80，90，100, および $150 \mu \mathrm{m}$ の凸パター ン露光用, 凹パターン露光用, ならびにライン＆スペース パターン露光用である.

$\mathrm{X}$ 線回折の影響を調べるため, 図 7 に示す微細パターン

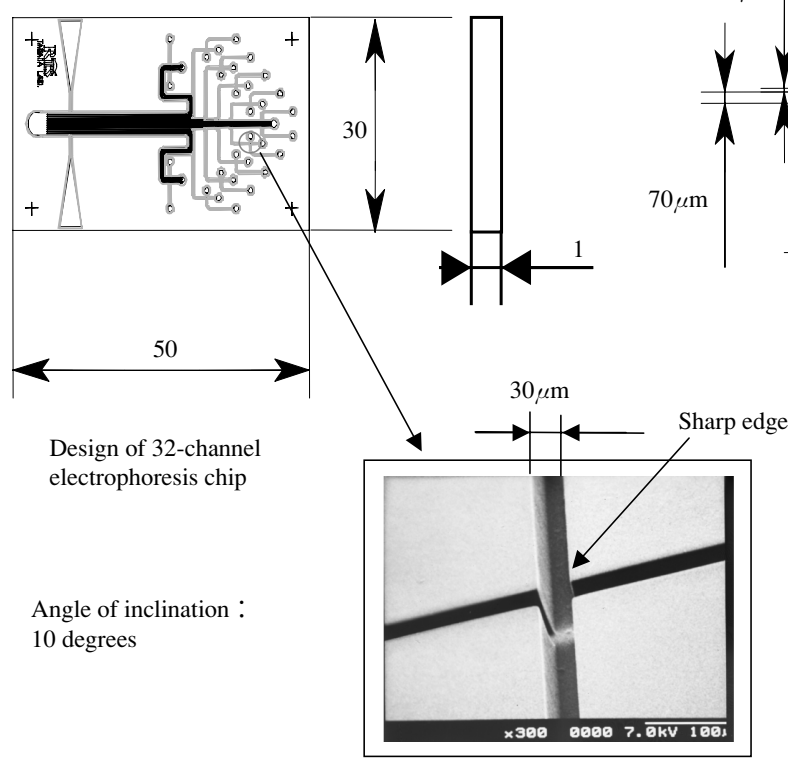

Angle of inclination : 10 degrees
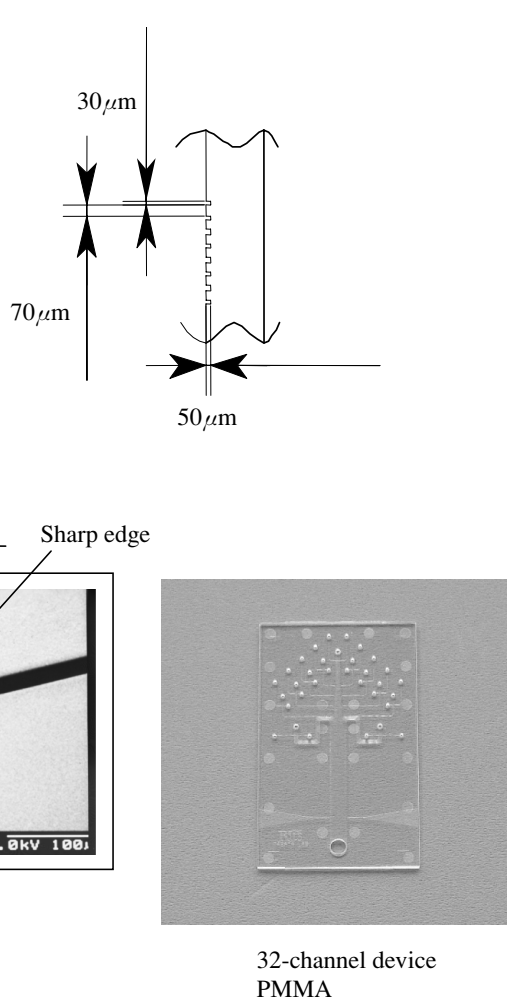

図 632 流路電気泳動デバイス（PMMA 製） 


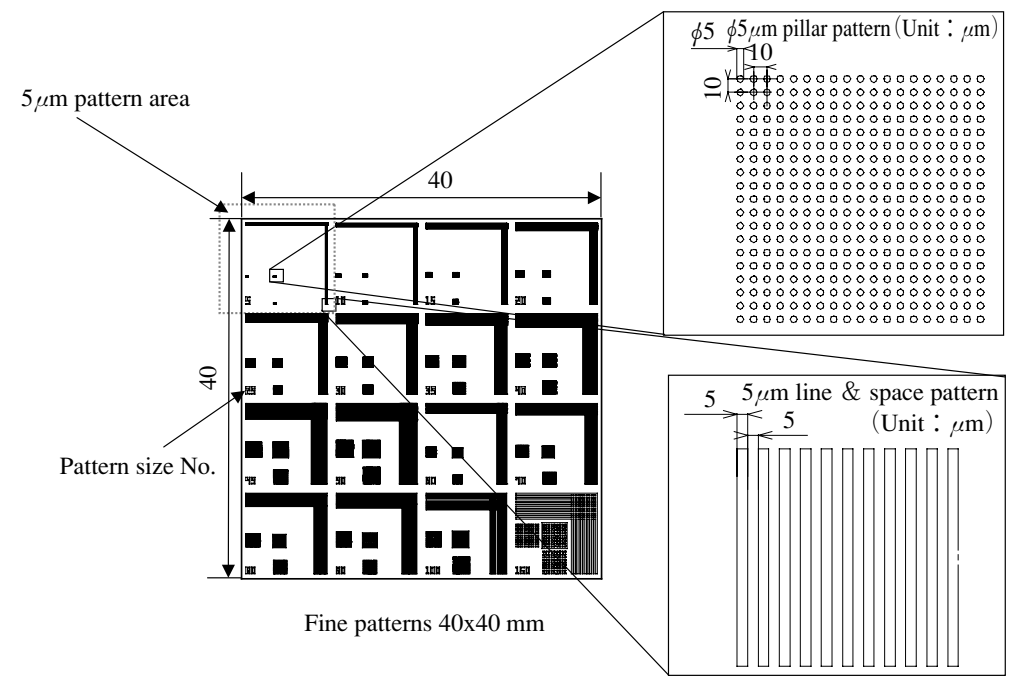

图 $7 \quad \mathrm{X}$ 線回折検討用の微細パターンレイアウト

表 2 SR 露光条件

\begin{tabular}{c|c|c|c|c}
\hline No & 1 & 2 & 3 & 4 \\
\hline Distance $(\mu \mathrm{m})$ & 0 & 500 & 1000 & 5000 \\
\hline
\end{tabular}

Distance is a moving clearance between an X-ray mask and a PMMA plate.
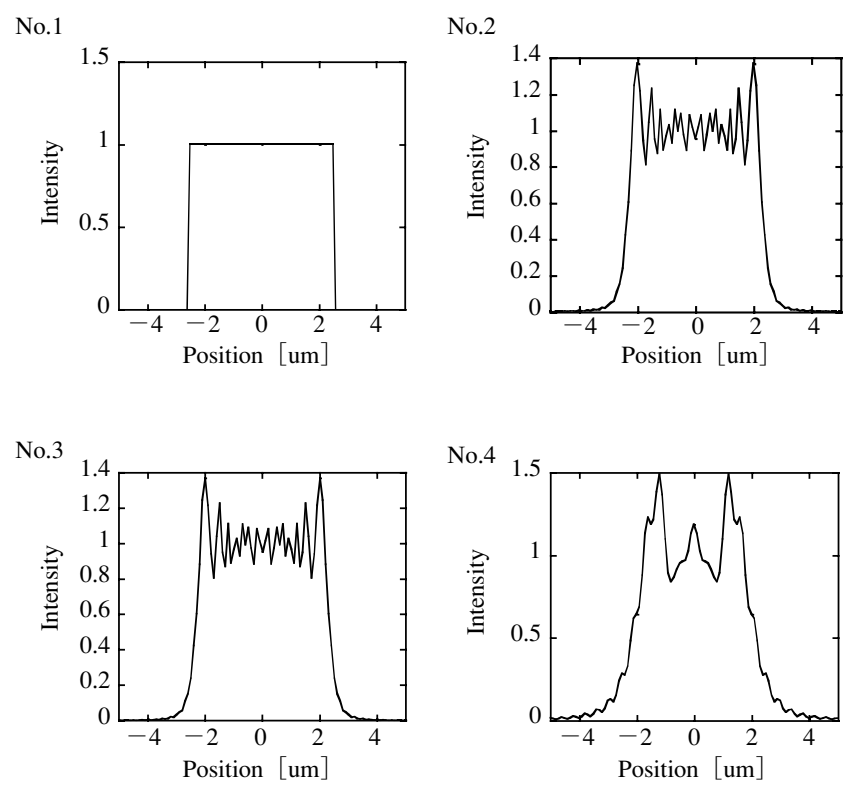

図 $8 X$ 線回折シミュレーション解析結果

を表 2 の SR 露光条件で PMMA 基板上に露光した後, 最 もパターンが微細である $5 \mu \mathrm{m}$ パターンに限定して, $5 \mu \mathrm{m}$ パターンエリア内の $5 \mu \mathrm{m}$ ライン\&スペースパターンと 5 $\mu \mathrm{m}$ 凸パターンそれぞれの形状を, 走査型電子顕微鏡 (SEM) で観察した. なお, 露光深さは $20 \mu \mathrm{m}$ とした.

また, サブナノメートルの X 線波長で, 表 2 の SR 露光 条件で $5 \mu \mathrm{m}$ ライン\&スペースパターンを露光する場合の $\mathrm{X}$ 線回折のシミュレーション解析を, 京都大学の田畑研究 室にて実施した. 図 8 に同条件において $5 \mu \mathrm{m}$ ライン\&ス ペースパターンをX 線マスクを動かさずに（移動マスク

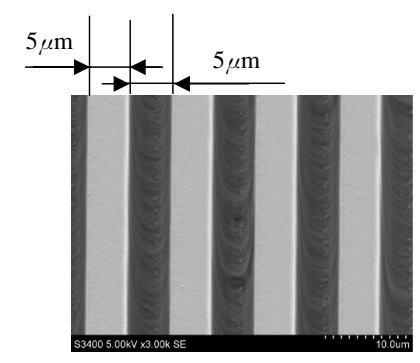

No.1

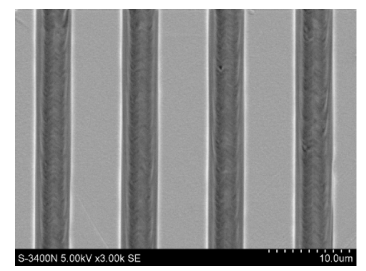

No.3

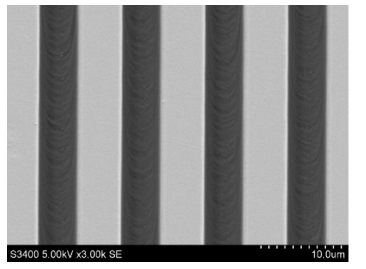

No. 2

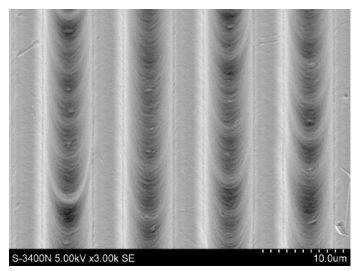

No.4
図 9 PMMA 基板に露光した $5 \mu \mathrm{m}$ ライン \&スペース パターンの SEM 写真

法を使用しないで)，PMMA 基板上に露光する場合の X 線回折シミュレーション結果を示す。同図は縦軸が $\mathrm{X}$ 線 マスクを通過する際の X 線強度，横軸をマスク開口部の 大きさ $(5 \mu \mathrm{m})$ で整理した．X線回折現象が生じなけれ ば，図 8 の No.1に示したようにX 線解析線図は，X 線強 度が 1 を示す矩形形状となり，X 線回折現象が大きくなる に従って, 解析線図が矩形形状から崩れる結果となる.従っ て, X 線回折現象は, No. $1<$ No. $2<$ No. $3<$ No. 4 の順に 大きくなり, 特にNo. 4 で回折現象が最も大きくなること が明らかとなった.

表 2 の SR 露光条件で PMMA 基板に露光した $5 \mu \mathrm{m}$ ラ イン\&スペースパターンならびに $5 \mu \mathrm{m}$ 凸パターン，それ ぞれの SEM 観察結果を図 9, 図 10 に示す. $5 \mu \mathrm{m}$ ライン \&スペースパターンおよび $5 \mu \mathrm{m}$ 凸パターンの露光深さは 共に $20 \mu \mathrm{m}$ である. 図 9 の $5 \mu \mathrm{m}$ ライン\&スペースパター 
ンでは，X 線マスクと PMMA 基板との距離が長くなるに つれて回折現象が生じていることが判りにくい結果となっ たが，図 10 に示した $5 \mu \mathrm{m}$ 凸パターンの SEM 写真からで は, X 線回折シミュレーション解析の結果どおりに X 線 マスクと PMMA 基板との距離が長くなるにつれて X 線 回折現象が大きくなっていることが確認される. 特に, $5 \mu \mathrm{m}$ パターンを PMMA 基板に露光する場合, $\mathrm{X}$ 線マス クと PMMA 基板との距離が $5000 \mu \mathrm{m}$ になると X 線回折 の影響を大きく受けることが判る. 以上のことから， $5 \mu \mathrm{m}$ レベルの微細な形状を SR 露光する場合は, 移動クリアラ
ンスを $1000 \mu \mathrm{m}$ 以下に設定する必要がある.

さらに，紫外線露光と比べて直線性がはるかに高い X 線を用いた SR 露光の深掘り露光について説明する. PMMA レジストに露光する形状を図 11 に示す. 露光す る形状は， $6.05 \mathrm{~mm} \times 4.20 \mathrm{~mm}$ エリアに六角形の対辺距 離が $104 \mu \mathrm{m}$, 六角形のパターン間隔が $20 \mu \mathrm{m}$ の連続パ ターンを形成したクラスターの集合体からなっている（1 クラスター内のハニカム数：60 個). このクラスターを横 方向 $150 \mu \mathrm{m}$, 縦方向 $100 \mu \mathrm{m}$ のクラスター間隔で $5 \times 5$ 配 列してある.このパターンのX線マスクを製作して

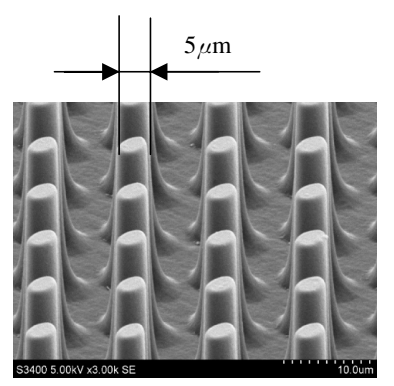

No.1

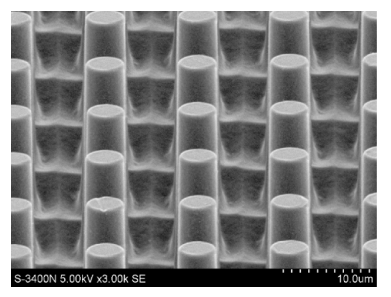

No.3

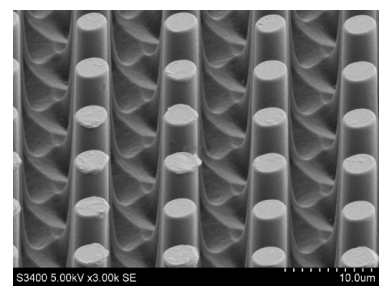

No. 2

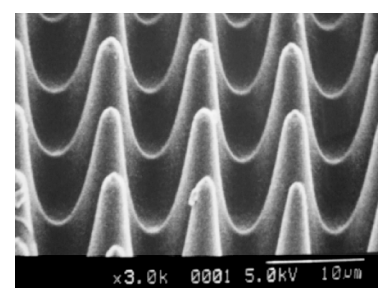

No.4

図 10 PMMA 基板に露光した $5 \mu \mathrm{m}$ 凸パターンの SEM 写真

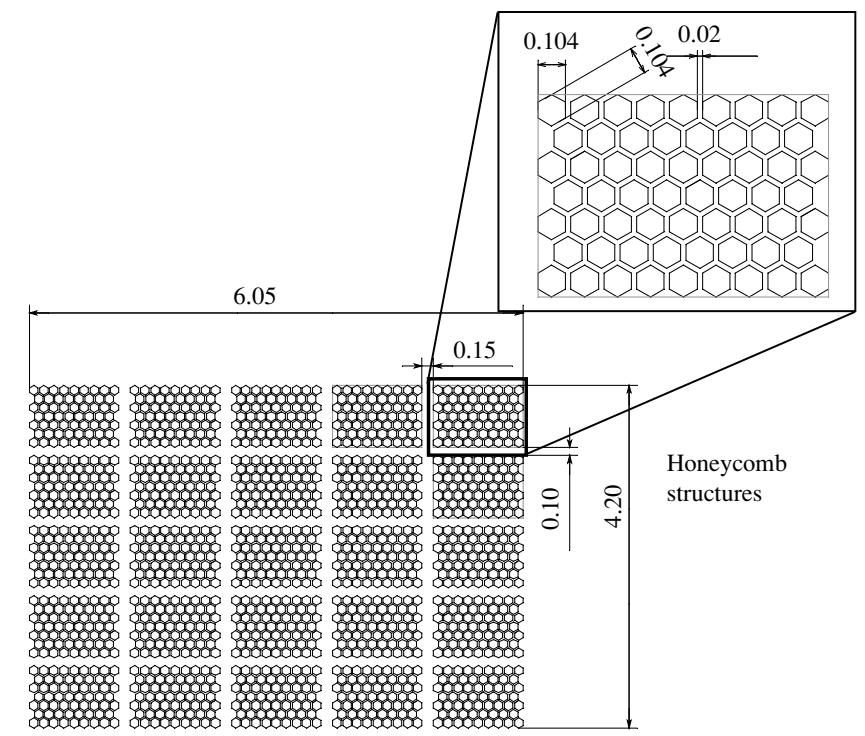

図 11 深掘り露光用のパターンレイアウト
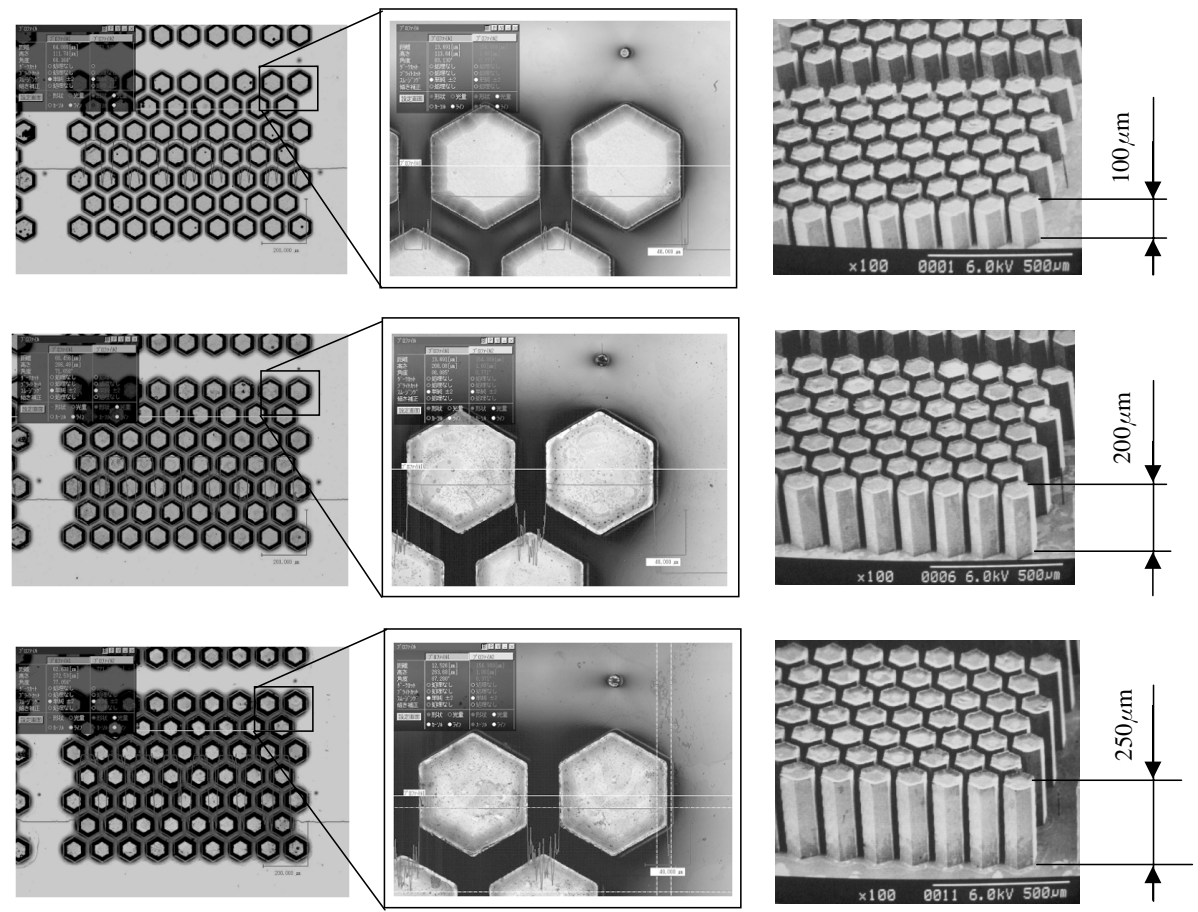

Laser microscope photographs

SEM photographs

図 $12 \mathrm{Ni}$ 電鋳金型の微細形状観察結果 
PMMA 基板に $100 \mu \mathrm{m}, 200 \mu \mathrm{m}$ ，および $250 \mu \mathrm{m}$ の深さま で露光できるよう X 線を照射した。なお，X線の直線性を 検討するため, 断面側壁に傾斜を設けない条件で PMMA 基板に図 11 のハニカム形状を露光した. 各露光深さの八 ニカム構造を PMMA 基板に露光した後, $\mathrm{Ni}$ 電鋳工程を 経て $\mathrm{Ni}$ 電鋳金型を製作した。この Ni 電鋳金型における各 ハニカム構造パターンをレーザ顕微鏡と SEM で観察した 結果を図 12 に示す.図 12 の $250 \mu \mathrm{m}$ の高さの $\mathrm{Ni}$ 電鋳金型 のハニカム構造から, X 線回折の影響を十分に考慮すれば, $250 \mu \mathrm{m}$ のほぼ垂直の深掘り露光が可能であることが判る.

図 13 に $250 \mu \mathrm{m}$ 高さの $\mathrm{Ni}$ 電鋳の六角形の天面部の SEM 写真を示す (PMMA 基板では露光底面に相当する). 同図より，六角形の外周部が若干盛り上がった形状になっ ている.この結果は $250 \mu \mathrm{m}$ の場合のみの現象ではなく, $100 \mu \mathrm{m}$ ，あるいは $200 \mu \mathrm{m}$ の場合にも確認された。露光 パターンの外周部が深く露光される原因は, $\mathrm{X}$ 線マスクの パターンエッジ部でX 線が強調されることにあると推察 される.この現象を防止するには，シリコン基板あるいは 金属基板上にPMMA レジストを所定膜厚に成膜したレジ スト基板を用いて, 基板面まで露光をする (貫通露光法)必

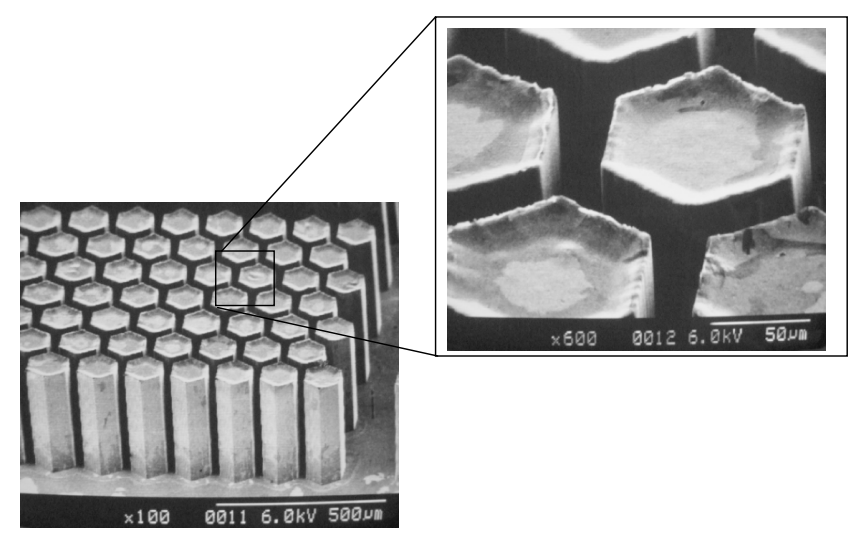

図 $13250 \mu \mathrm{m}$ 高さのハニカム構造 $\mathrm{Ni}$ 電鋳金型
要がある.しかし, シリコン基板あるいは金属基板上への PMMA レジストの成膜は, 成膜エリアが広くなるほど, ま た厚膜になるほど均一な成膜が難しくなる.そこで, スター ライト工業(侏)では, 上述した貫通露光法に加えて, SR 露光 時にX 線マスクを移動させる移動マスク法が，露光外周 部の盛り上がり防止対策に効果があることを明らかにした.

\section{4. 多段露光プロセス}

図 1 に示した LIGA プロセスでは, SR を用いて PMMA 基板に数百 $\mu \mathrm{m}$ の微細パターンを露光することができる ことを示したが, 露光エリア内にパターンの位置を制御し ながら複数の露光深さを形成させることは困難である.そ こで, SR 露光プロセスで, X 線マスクにアライメントマー クを数力所設けて数枚の X 線マスクを組み合わせて, 所 定の Dose に達した毎にX 線マスクを取り外すという多段 階露光プロセスについて説明する．図 14 にX 線マスクを 2 枚組み合わせた場合の SR 露光プロセスを示す ${ }^{12)}$. X 線 マスクを組み合わせた状態でマスクパターンに位置ずれが あると, PMMA 基板にその位置ずれに相当したパターン が露光されることになるため，この多段階露光プロセスで は，X線マスク上に形成したパターンの位置合わせが非常 に重要である.

微細パターンの断面傾斜角を 10 度になるように, 2 枚 のX 線マスクを組み合わせて SR 露光することで, 図 15 に示すような流路系マイクロデバイスのマイクロ流路の両 側にカバープレートの接合を担うマイクロリブを形成する ことが可能となる.

X 線マスクの微細パターンの位置ずれをアライメント マークで制御することで, SR 露光プロセスにおける多段 階の SR 露光が可能となり, 露光エリア内で露光深さが異 なる複数のパターンを露光できる。 また，PMMA 基板に 作製する複数の深さの異なるパターンは, X 線マスク上の アライメントマークを, PMMA 基板に形成したアライメ ントマークと合わせることでも可能である.
1 st step

SR conditions :

Dose $: 0.4 \mathrm{~A} \cdot \mathrm{h}$

Scan length $: 80 \mathrm{~mm}$

2nd step

SR conditions :

\section{Dose $: 0.1 \mathrm{~A} \cdot \mathrm{h}$}

Scan length $: 80 \mathrm{~mm}$

Cross section of micro structures
Mask 1

Mask 2
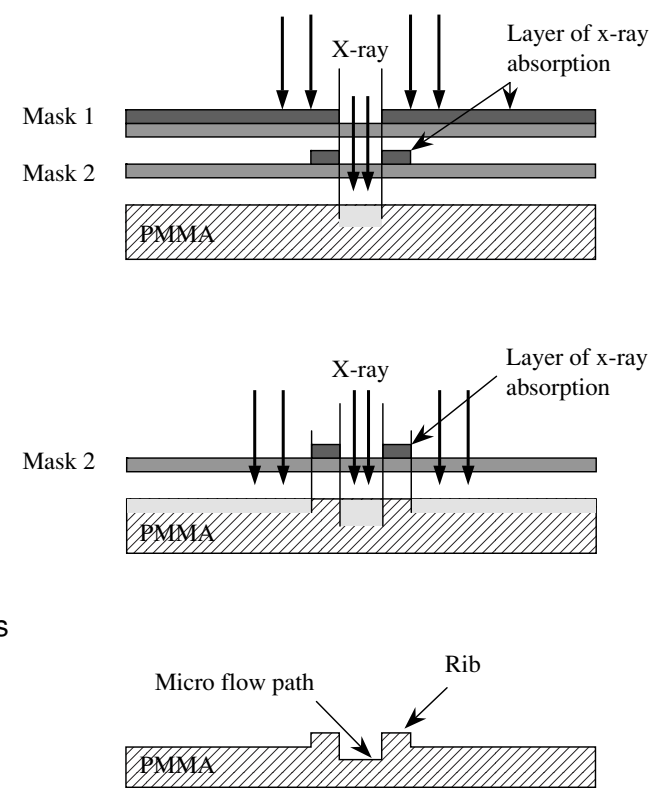

図 142 段階露光プロセス 


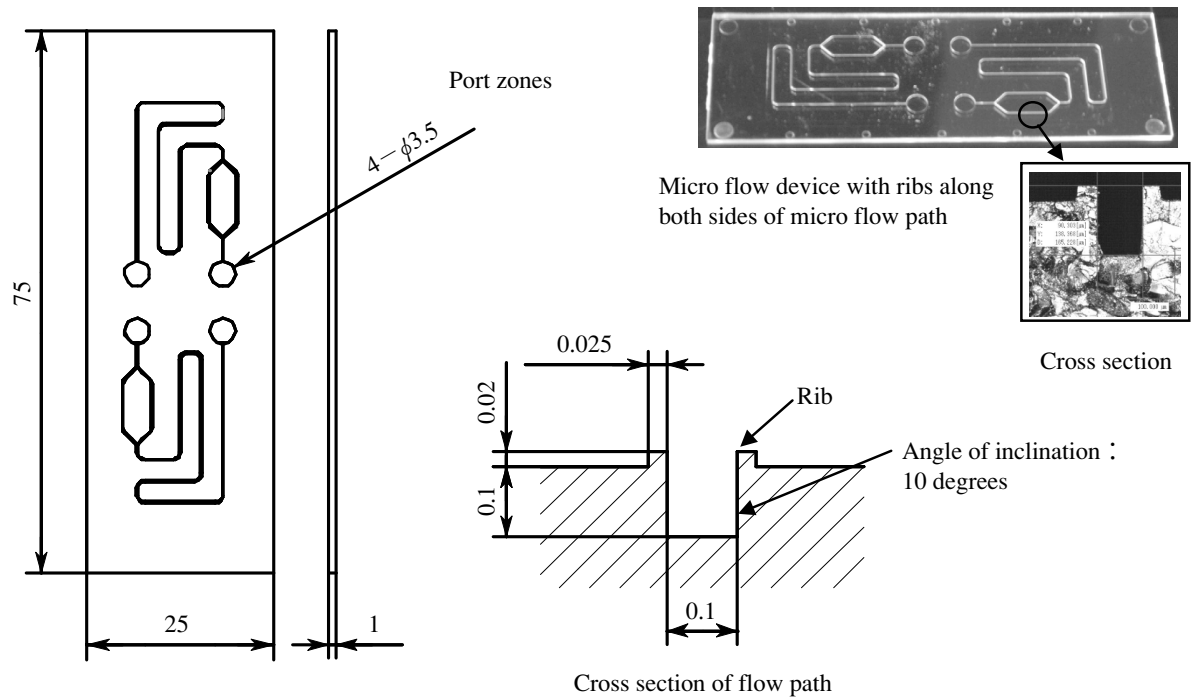

図 152 段階露光プロセスで製作した PMMA 製のリブ付きマイクロデバイス. 2 段階露光プロセスにより露光深さを変えることでリブ部を形成

\section{5. ま と}

バイオ，医療，通信ならびに光分野への応用展開を目指 して，1990 年代頃から急速に開発検討が行われてきたマ イクロデバイスを，高い形状再現性と低価格で生産するプ ロセスの1つとして LIGA プロセスがあることを説明した. 射出成形という成形手法は，金型が製作でき，成形材料， 微細パターン形状ならびに成形品厚みなどを考虑して最適 な成形条件が設定できれば，マイクロメータからナノメー 夕の形状再現性で, 1 枚/分から数枚/分の成形サイクルで マイクロデバイスを生産できる.しかし,射出成形でスムー スにマイクロデバイスを金型から離型させるには，微細パ ターンの断面側壁に 10 度から 20 度程度の傾斜が必要であ り，マイクロデバイスのパターンが微細になればなるほど, この微細断面の傾斜角がたいへん重要となる. Ni 電鋳工 程で使用するマスター型は, LIGA プロセスで製作した PMMA 基板以外に，冒頭で述べたシリコン基板を用いる 場合がある. シリコン基板での深掘り加工法の一例として, Bosch プロセスを用いた ICP (inductively coupled plasma）エッチング装置による加工法がある.この加工 法では，側壁部にわずかに順テーパの傾斜を付けた深掘り 加工が可能となるものの, 加工条件を最適化できなければ, 加工深さ方向に平行の筋模様が入り, この筋模様が射出成 形でマイクロデバイスを離型する方向に対して直行してい るため, 離型抵抗が大きくなる危険性がある。一方, 微細 形状の断面側壁に任意の傾斜角を付けられる LIGA プロセ スは, SR 露光工程で X 線マスクを組み合わせることで露 光深さが異なるパターンを PMMA 基板に形成できること も相まって, 射出成形でマイクロデバイスを生産するため の魅力的な手法の 1 つである.

$\mathrm{X}$ 線露光を行う SR 施設はたいへん限られているが, 三
次元微細構造体を大量生産するための金型製作の 1 手法と して，今後，広く利用させることを期待したい。本報が， LIGA プロセスの普及の一助となれば幸いである.

\section{参 考 文 献}

$1)$ Chujo, H. et al. : The $16^{\text {th }}$ IEEE International Conference on Micro Electro Mechanical Systems, 351 (2003)

2 ) Min, K. et al. : The $16^{\text {th }}$ IEEE International Conference on Micro Electro Mechanical Systems, 379 (2003)

3 ) Kim, S. et al. : The $16^{\text {th }}$ IEEE International Conference on Micro Electro Mechanical Systems, 435 (2003)

4 ) Becker, E. W. et al. : Natuwissenschaften, 69, 520 (1982)

5 ) Jurischka, R. et al. : Proceedings of $\mu$ TAS 2006 conference, 146 (2006)

6 ) Melin, J. et al. : Proceedings of $\mu$ TAS 2006 conference, 422 (2006)

7 ) Ekstrom, S. et al. : Proceedings of $\mu$ TAS 2006 conference, 1468 (2006)

8 ）田畑 修: 成形加工, 15(4), 246 (2003)

9 ) Kurokawa, M. et al. : Nanotechnology Researchers Network Project, Technical Reports 2005 in the SR CENTER of Ritsumeikan University, 85 (2005)

10) Kitadani, T. et al. : Proceedings of the $19^{\text {th }}$ Sensor Symposium, 327 (2002)

11）黑川正也ら：日本機械学会年次大会予稿集, 489 (2004)

12）黑川正也ら：日本機械学会年次大会予稿集, 169 (2006) 